\title{
Low-temperature Germination of Melons Is Affected by Seedcoat Characteristics and Embryo Genotype
}

\author{
Menahem Edelstein ${ }^{1}$ and Haim Nerson \\ Department of Vegetable Crops, Agricultural Research Organization, Newe \\ Ya'ar Research Center, P.O. Box 1021, Ramat Yishay 30095, Israel \\ Additional index words. Cucumis melo, germination percentage, inheritance, mean days to
germination
}

\begin{abstract}
Germination percentage and germination rate were examined in two melon accessions differing in their ability to germinate under low temperature and in their reciprocal $\mathrm{F}_{1}, \mathrm{~F}_{2}$, and $\mathrm{BC}_{1}$ progeny. The seedcoat structure, pressure force required for seedcoat splitting, and the response to hilum sealing of the reciprocal $F_{1} s$ were examined as well. The purpose of this study was to elucidate the effects of embryonic genotype and seedcoat characteristics on the ability of melon seeds to germinate under low temperature. The results of the study point out that both components are strongly involved in low-temperature germination. The cold tolerant parent, 'Persia 202' (P202), germinated greater than $90 \%$ at $15^{\circ} \mathrm{C}$, whereas the cold-sensitive parent, 'Noy Yizre'el' (NY), did not germinate at all. The $\mathrm{P} 202 \times \mathrm{NY} \mathrm{F}_{1}$ and the reciprocal $\mathrm{F}_{2}$ germinated $80 \%$ to $90 \%$, whereas the $\mathrm{NY} \times \mathrm{P}_{202} \mathrm{~F}_{1}$ germination percentage was only $71 \%$. Backcrosses of the reciprocal $F_{1}$ to the parents revealed that if the cross was to the tolerant one, the seeds germinated greater than $90 \%$, but if the $F_{1}$ s were backcrossed to the sensitive parent, the seeds had only $56 \%$ to $60 \%$ germination. Data collected suggest that several dominant genes are carried by $\mathbf{P 2 0 2}$ for low-temperature germination. On the other hand, the difference in germination percentages between the reciprocal $F_{1}$ demonstrates that the different seedcoats also play a role.
\end{abstract}

Germination of melon seeds at low temperatures is cultivar-dependent. By screening hundreds of accessions (Nerson and Edelstein, 1982-1984, unpublished data), it was concluded that a temperature of 14 to $15{ }^{\circ} \mathrm{C}$ can be used to distinguish between few low-temperature germinating and many nongerminating accessions. Among the lowtemperature germinating accessions, three birdsnest lines from Iran germinated after $12 \mathrm{~d}$ of incubation at $15{ }^{\circ} \mathrm{C}$ and their germination was accelerated by several pregermination treatments (Edelstein and Kigel, 1990; Nerson et al., 1982). The threshold temperature for germination in one of these lines ['Persia 202' (P202)] was found to be 10 to $11^{\circ} \mathrm{C}$, but under this low temperature, germination was partial (less than $50 \%$ ) and nonuniform (Edelstein and Kigel, 1990).

The ability to improve vegetable seed germination at suboptimal temperatures by infusion of phytohormones or plant growth regulators (PGRs) into the seeds was first reported by Wittwer and Bukovac (1957). Application of this idea in cucurbit seeds was reported more than 20 years later. Pregermi-

Received for publication 16 Mar. 2009. Accepted for publication 5 May 2009.

Contribution from the Agricultural Research Organization, The Volcani Center, Bet Dagan, Israel, No. $110 / 2009$.

${ }^{1}$ To whom reprint requests should be addressed; e-mailmedelst@volcani.agri.gov.il.
Govers, 1986). Later studies revealed that the ability of the birdsnest line P202 to germinate at low temperature was accompanied by a relatively high endogenous gibberellin content (Edelstein et al., 1995a) and high metabolic activity (Edelstein et al., 2001).

The anatomical structure of the seedcoat acts in many species as a physical barrier to gas exchange and/or to radicle breakthrough. In Beta vulgaris (Coumans et al., 1976; Santos and Pereria, 1989) and Datura sp. (Reisman-Berman et al., 1989), the hilum was found to be the main pathway for gas exchange, and sealing the hilum prevented germination because oxygen diffusion through the seedcoat surface was not sufficient. Similar results were reported in 'Noy Yizre'el' (NY) melon but not in P202 (Edelstein et al., 1995b).

Genetic analysis of the relative importance of the embryo and seedcoat in lowtemperature germination is complicated because the embryo is developed from both the donor and the recipient parents, whereas the seedcoat is of maternal origin only. For example, $\mathrm{F}_{2}$ and $\mathrm{BC}_{1}$ or the maternal parents and $F_{1}$ seeds have different genotypic embryos but the same seedcoat genotype. Hutton and Loy (1992) did a genetic analysis of cold germinability in muskmelon by crossing a cold-germinable line to a noncold-germinable line and testing the germinability of the parents and the reciprocal $\mathrm{F}_{1}, \mathrm{~F}_{2}$, and $\mathrm{BC}_{1}$ at $15{ }^{\circ} \mathrm{C}$ for $14 \mathrm{~d}$. They concluded that three to four recessive genes and a cytoplasmatic factor controlled lowtemperature germination, but they did not examine the role of the seedcoat. In nation treatments like exogenous application of PGR or osmoconditioning are effective tools in improving melon seed germination (Nelson and Sharples, 1980; Nerson and
Table 1. Germination percentage and mean days to germination (MDG) of Noy Yizre'el (NY), Persia 202 (P202), and their reciprocal $\mathrm{F}_{1}, \mathrm{~F}_{2}$, and $\mathrm{BC}_{1}$ incubated at 15 and $28^{\circ} \mathrm{C}$.

\begin{tabular}{|c|c|c|c|c|c|c|}
\hline \multirow[b]{2}{*}{ Generation } & \multicolumn{2}{|c|}{ Genotype } & \multicolumn{2}{|c|}{ Germination (\%) } & \multicolumn{2}{|c|}{ MDG (days) } \\
\hline & Embryo & Seedcoat & $15^{\circ} \mathrm{C}$ & $28^{\circ} \mathrm{C}$ & $15^{\circ} \mathrm{C}$ & $28^{\circ} \mathrm{C}$ \\
\hline$\overline{\mathrm{P}_{1}(\mathrm{P} 202)}$ & $\mathrm{P}_{1}$ & $\mathrm{P}_{1}$ & $96 \mathrm{a}^{\mathrm{z}}$ & $99 \mathrm{a}$ & $6.7 \mathrm{f}$ & $1.3 \mathrm{~b}$ \\
\hline $\mathrm{P}_{2}(\mathrm{NY})$ & $\mathrm{P}_{2}$ & $\mathrm{P}_{2}$ & $2 \mathrm{f}$ & $89 \mathrm{ab}$ & - & $3.0 \mathrm{a}$ \\
\hline $\mathrm{F}_{1}\left(\mathrm{P}_{1} \times \mathrm{P}_{2}\right)$ & $\mathrm{F}_{1}$ & $\mathrm{P}_{1}$ & $85 \mathrm{bc}$ & $94 \mathrm{ab}$ & $8.0 \mathrm{c}-\mathrm{e}$ & $1.4 \mathrm{~b}$ \\
\hline $\mathrm{F}_{1}\left(\mathrm{P}_{2} \times \mathrm{P}_{1}\right)$ & $\mathrm{F}_{1}$ & $\mathrm{P}_{2}$ & $71 \mathrm{~d}$ & $83 \mathrm{~b}$ & $12.1 \mathrm{a}$ & $2.8 \mathrm{a}$ \\
\hline$F_{2}\left(P_{1} \times P_{2}\right) \otimes$ & $\mathrm{F}_{2}$ & $\mathrm{~F}_{1}$ & $82 \mathrm{c}$ & $97 \mathrm{a}$ & $9.2 \mathrm{c}$ & $1.3 \mathrm{~b}$ \\
\hline$F_{2}\left(P_{2} \times P_{1}\right) \otimes$ & $\mathrm{F}_{2}$ & $F_{1}$ & $88 \mathrm{a}-\mathrm{c}$ & $98 \mathrm{a}$ & $8.3 \mathrm{~cd}$ & $1.2 \mathrm{~b}$ \\
\hline $\mathrm{BC}_{1}\left(\mathrm{P}_{1} \times \mathrm{P}_{2}\right) \times \mathrm{P}_{1}$ & $3 / 4 \mathrm{P}_{1}$ & $F_{1}$ & $94 \mathrm{ab}$ & $96 \mathrm{ab}$ & $7.8 \mathrm{~d}-\mathrm{f}$ & $1.2 \mathrm{~b}$ \\
\hline $\mathrm{BC}_{1}\left(\mathrm{P}_{1} \times \mathrm{P}_{2}\right) \times \mathrm{P}_{2}$ & $3 / 4 \mathrm{P}_{2}$ & $\mathrm{~F}_{1}$ & $56 \mathrm{e}$ & $94 \mathrm{ab}$ & $10.7 \mathrm{~b}$ & $1.4 \mathrm{~b}$ \\
\hline $\mathrm{BC}_{1}\left(\mathrm{P}_{2} \times \mathrm{P}_{1}\right) \times \mathrm{P}_{2}$ & $3 / 4 \mathrm{P}_{2}$ & $\mathrm{~F}_{1}$ & $60 \mathrm{e}$ & $99 \mathrm{a}$ & $11.0 \mathrm{ab}$ & $1.2 \mathrm{~b}$ \\
\hline$\underline{B C_{1}}\left(P_{2} \times P_{1}\right) \times P_{1}$ & $3 / 4 \mathrm{P}_{1}$ & $F_{1}$ & $97 \mathrm{a}$ & $99 \mathrm{a}$ & $6.9 \mathrm{ef}$ & $1.2 \mathrm{~b}$ \\
\hline
\end{tabular}

${ }^{2}$ Values followed by a different letter differ significantly $(P=0.05)$ according to Duncan's multiple range test.

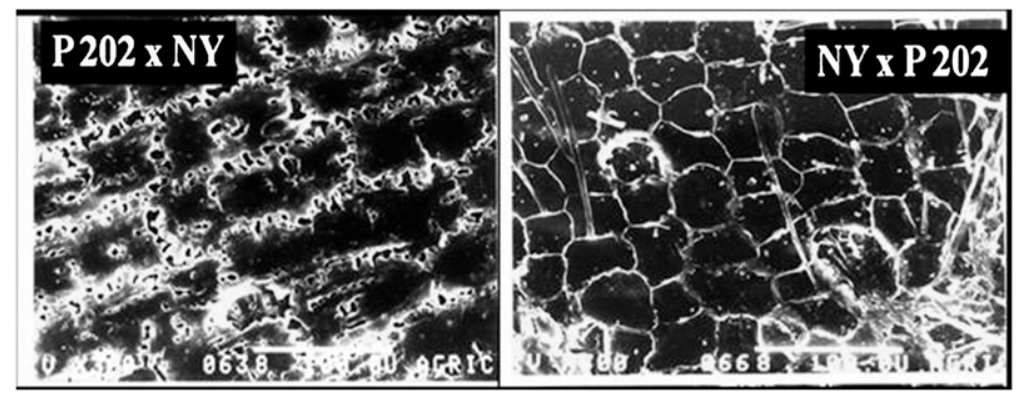

Fig. 1. Scanning electron micrograph of the external surface of the seedcoat in the reciprocal $F_{1} s$. Bars indicate $100 \mu \mathrm{m}$. 

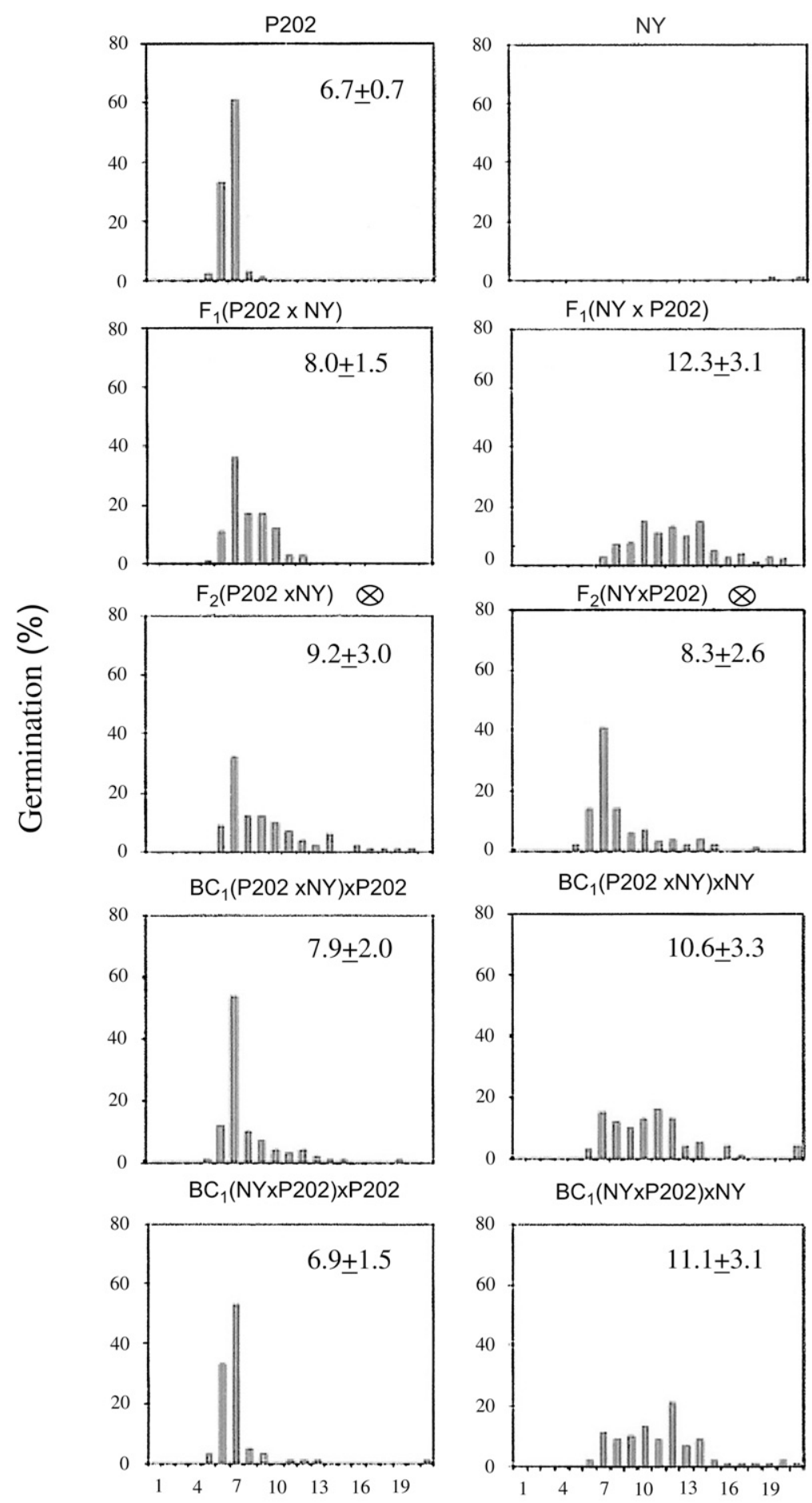

Days to germination

Fig. 2. Days to germination at $15{ }^{\circ} \mathrm{C}$ in $\mathrm{P} 202$, $\mathrm{NY}$, and their reciprocal $\mathrm{F}_{1}, \mathrm{~F}_{2}$, and $\mathrm{BC}_{1}$. Values in each subfigure represent mean days to germination $\mathrm{AD}$.

contrast, other studies, using different genetic material, pointed out that dominant gene(s) are responsible for germination under low temperature (Nerson and Staub, 1989).

The main goal of the present study was to further examine the relative importance of the physical and anatomical characteristics of the seedcoat to the genotype in determining low-temperature germinability in muskmelon.

\section{Materials and Methods}

Melon seed of cultivars NY and P202, and their reciprocal $\mathrm{F}_{1}, \mathrm{~F}_{2}$, and $\mathrm{BC}_{1}$ were produced at the Newe Ya'ar Research Center and stored in the dark at $10 \pm 2{ }^{\circ} \mathrm{C}$ and $45 \%$ to $55 \%$ relative humidity. Two germination tests of all generations were carried out under temperature-controlled chambers under 28 and $15^{\circ} \mathrm{C}$ in the dark. Seeds were placed in

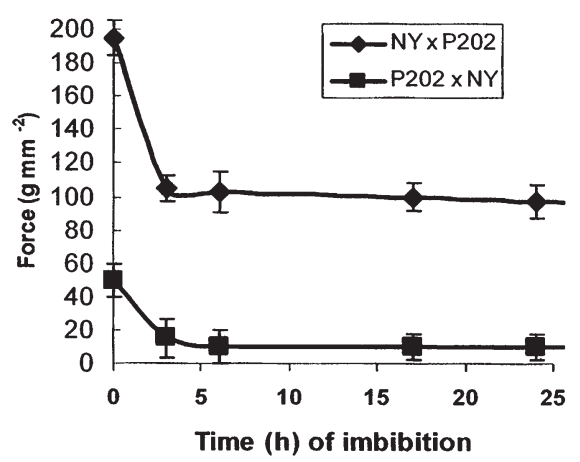

Fig. 3. Force needed to penetrate the seedcoat at the hilum end in seeds of the reciprocal $F_{1}$ incubated at $15^{\circ} \mathrm{C}$ as measured by a penetrometer. Vertical bars represent \pm SE.

9-cm petri dishes on Whatman No. 3 filter paper saturated with $5 \mathrm{~mL}$ distilled water. There were 25 seeds per dish and four replicates per treatment. Seed germination was recorded daily for 7 and $21 \mathrm{~d}$ at $28^{\circ}$ and $15{ }^{\circ} \mathrm{C}$, respectively. A seed was considered germinated when its radicle was longer than $3 \mathrm{~mm}$ (Hutton and Loy, 1992). Germination rate was determined by calculation of the mean number of days to germination (MDG) as described previously (Edelstein and Kigel, 1990).

The structure of the external surface of the seedcoat was examined by scanning electron microscope (Jeol JSN 35C) at $25 \mathrm{kV}$ acceleration voltage. Dry seeds were directly coated with gold (20 to $22 \mathrm{~nm}$ in thickness) (Edelstein et al., 1995b).

The mechanical resistance of the seedcoat was determined in 20 seeds with a penetrometer (John Chatilon \& Sons, New York, NY), the tip of which was molded to the shape and size of the radicle. The embryo was removed and the force was determined from the inside out, at the hilum, in dry and imbibed seeds during the first $25 \mathrm{~h}$ of imbibition (Edelstein et al., 1995b).

Determination of seed germination under the limit of gas exchange was evaluated by sealing the hilum, the micropylar region of the seed, with lanoline (Sigma) in four replicates of 25 seeds each (Edelstein et al., 2001).

Statistical differences among the generation families with respect to germination data were determined by analysis of variance and Duncan's multiple range test. The data of germination percentages were arcsin-transformed before calculating. The variation of germination under low temperature was expressed as mean days to germination $\pm \mathrm{SD}$. The differences between the reciprocal $F_{1}$ with respect to the force required to split the coat and their ability to germinate after sealing the hilum are presented as means $\pm \mathrm{SE}$.

\section{Results and Discussion}

Germination percentages of P202, NY, and their reciprocal $\mathrm{F}_{1}, \mathrm{~F}_{2}$, and $\mathrm{BC}_{1}$ at $28^{\circ} \mathrm{C}$ 
were mostly greater than $90 \%$ and generally did not differ from each other (Table 1). In contrast, germination rates at the same temperature showed large significant differences between P202 and NY and between the reciprocal $F_{1}$, whereas the $F_{2}$ and the four $\mathrm{BC}_{1}$ generations germinated as fast as P202. These data revealed that all seed generations in the present study were vigorous seeds and germinated well, whereas the germination rate was affected by seedcoat characters and not only by the embryo genotype (Edelstein and Kigel, 1990). P202 and P202 × NY have the same seedcoat characterized by intercellular spaces in the outer layers (Edelstein et al., 1995a) (Fig. 1) and lower MDG values than $\mathrm{NY}$ and $\mathrm{NY} \times \mathrm{P} 202 . \mathrm{F}_{2}$ and $\mathrm{BC}_{1}$ generations have the same seedcoat genotype $\left(\mathrm{F}_{1}\right)$ and, despite having $25 \%$ to $75 \%$ of NY genome, were able to germinate, under optimal temperature, as fast as P202. The two parental accessions differed significantly in their germination responses to low temperature, full germination in P202 and almost nil in NY. Germination percentages and rates in $\mathrm{F}_{1}, \mathrm{~F}_{2}$, and $\mathrm{BC}_{1}$ families show low-temperature germination depends both on seedcoat characters and on genotype. Relatively high germination percentages in all generations as compared with NY can be attributed to dominant gene(s) in P202 for low-temperature germination and perhaps to higher gibberellin content and metabolic activity compared with NY seeds (Edelstein et al., 1995a, 2001). Furthermore, the significant differences in germination percentages in the four $\mathrm{BC}_{1}$ families between those with three to four P202 and three to four NY genotypes when all of them have the same seedcoat genotype supports this idea. On the other hand, the lower germination percentage and the slower germination rate of $\mathrm{NY} \times \mathrm{P} 202$ as compared with P202 $\times$ NY, which have both the same embryonic genotype but different seedcoat (Fig. 1), demon- strates that the NY seedcoat structure, which reduces germination, plays a role in lowtemperature germination. The influence of the two parents on germination rate under low temperature was evident across all the generation families (Fig. 2). P202 had faster germination and less variability than NY as expressed by the MDG values and their SD, respectively. Hutton and Loy (1992) investigated the inheritance of low-temperature germination in muskmelon and concluded that three to four recessive genes and a cytoplasmic factor controlled cold germinability. The disagreement between this conclusion and the present data may be explained by using different genetic materials for lowtemperature germination, PI 126156 versus $\mathrm{P} 202$. This may indicate that different genes can be involved in the complicated process of germination.

The pressure necessary to split the seedcoat was mechanically measured and was four- to fivefold higher in $\mathrm{NY} \times \mathrm{P} 202$ than in its reciprocal hybrid. In both $F_{1} s$, this force significantly decreased after $3 \mathrm{~h}$ imbibition (Fig. 3) and then remained constant over the next $21 \mathrm{~h}$. The data obtained from $\mathrm{F}_{1}$ seeds are in line with earlier data from the parental generation (Edelstein et al., 1995b), which showed significant differences in the force needed to split NY and P202 seedcoats. This difference between the reciprocal hybrids supports and may explain the differences in germinability between each other (Table 1), although they have the same embryonic genotype.

Sealing the hilum with lanolin decreased germination of $\mathrm{NY} \times \mathrm{P} 202$ but not in the reciprocal P202 $\times$ NY seeds (Fig. 4). These results are very similar to earlier data (Edelstein et al., 1995b) in which germination of NY but not of P202 were inhibited by sealing the seed hilum with lanolin paste. Apparently, this similarity is expected because NY and
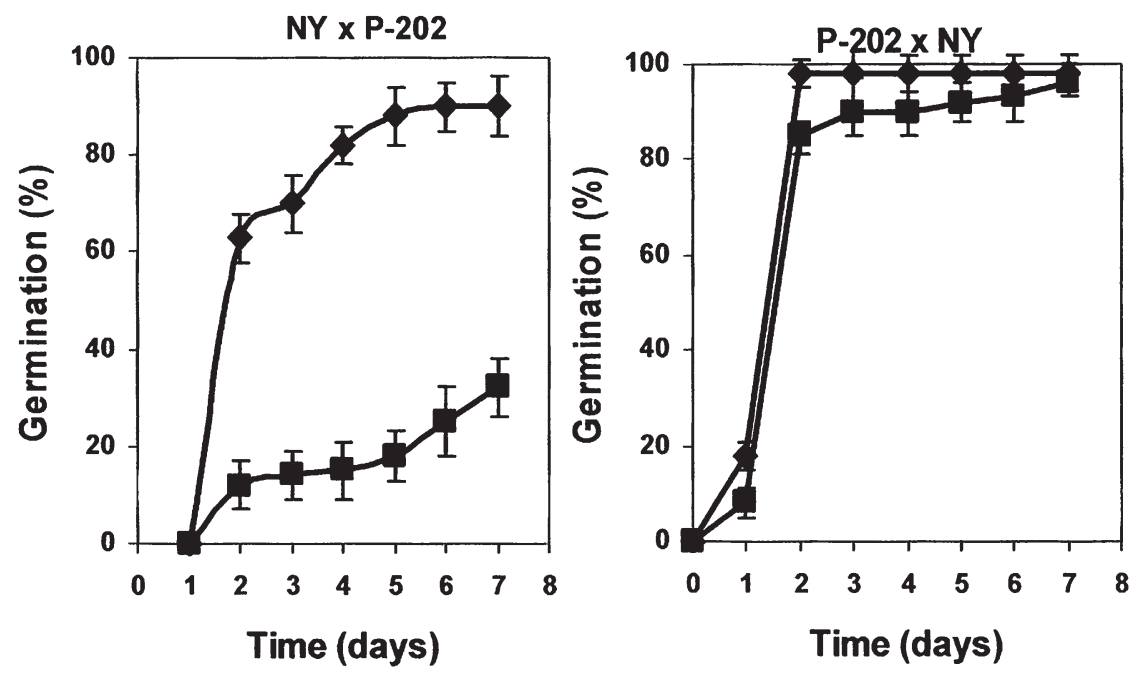

Fig. 4. Cumulative germination (\%) at $25^{\circ} \mathrm{C}$ of the reciprocal $\mathrm{F}_{1}$ as affected by sealing the hilum aperture with lanolin $(\bullet$ open hilum $=$ control, $\square$ closed hilum $)$. Vertical bars represent \pm SE.

$\mathrm{NY} \times \mathrm{P} 202$ or P202 and P202 $\times$ NY have the same seedcoat. However, NY and P202 have different embryonic genotypes, whereas the reciprocal $F_{1}$ have the same embryonic genotypes. Even so, the reciprocal $\mathrm{F}_{1}$ responded differently to hilum sealing. These data indicate the relative importance of seedcoat anatomical structure over the genotypic traits of the embryo. The role of the hilum, micropyle, and chalaza as main pathways for gas exchange in seeds was reported in different species (Coumans et al., 1976; ReismanBerman et al., 1989; Santos and Pereria, 1989). The present study shows that within melon species, differences exist with respect to this character, and probably gas exchange limitation prevented the germination of hilum-sealed seeds in NY (compacted seedcoat) but not in P202 (intercellular spaces in the seedcoat).

\section{Literature Cited}

Coumans, M., D. Come, and T. Gaspars. 1976. Stabilized dormancy in sugarbeet fruits. I. Seed coats as a physicochemical barrier to oxygen. Bot. Gaz. 137:274-278.

Edelstein, M., Y. Ben Tal, M. Wodner, and J. Kigel. 1995a. Role of endogenous gibberellins in germination of melon (Cucumis melo) seeds. Physiol. Plant. 95:113-119.

Edelstein, M., K.J. Bradford, and D.W. Burger. 2001. Metabolic heat and $\mathrm{CO}_{2}$ production rates during germination of melon (Cucumis melo L.) seeds measured by microcalorimetry. Seed Sci. Res. 11:265-272.

Edelstein, M., F. Corbineau, J. Kigel, and H. Nerson. 1995b. Seed coat structure and oxygen availability control low-temperature germination in melon (Cucumis melo) seeds. Physiol. Plant. 93:451-456.

Edelstein, M. and J. Kigel. 1990. Seed germination of melon (Cucumis melo) at sub- and supraoptimal temperatures. Scientia Hort. 45:55-63.

Hutton, M.G. and J.B. Loy. 1992. Inheritance of cold germinability in muskmelon. HortScience $27: 826-829$

Nelson, J.M. and G.C. Sharples. 1980. Effect of growth regulators on germination of cucumber and other cucurbit seeds at suboptimal temperatures. HortScience 15:253-254.

Nerson, H., D.J. Cantliffe, H.S. Paris, and Z. Karchi. 1982. Low temperature germination of birdnest-type muskmelons. HortScience 17:639-640.

Nerson, H. and A. Govers. 1986. Salt priming of muskmelon seeds for low- temperature germination. Scientia. Hort. 28:85-91.

Nerson, H. and J.E. Staub. 1989. Low temperature germination in muskmelon is dominant. Cucurbit Genet. Coop. Rpt. 12:50-51.

Reisman-Berman, O., J. Kigel, and B. Rubin. 1989. Short soaking in water inhibits germination of Datura ferox $\mathrm{L}$. and D. stramonium $\mathrm{L}$. seeds. Weed Res. 29:357-363.

Santos, D.S.B. and M.F.A. Pereria. 1989. Restriction of the tegument to the germination of Beta vulgaris L. seeds. Seed Sci. Technol. 17:601611.

Wittwer, S.H. and M.J. Bukovac. 1957. Gibberellin and higher plant. VIII. Seed treatments for beans peas and sweet corn. Mich. Agr. Expt. Sta. Quart. Bul. 40:215-224. 